\title{
Elevated serum TSH concentrations are associated with higher BMI Z-scores in southern Iranian children and adolescents
}

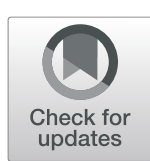

Ashkan Habib ${ }^{1}$, Mohadeseh Molayemat ${ }^{1}$ and Asadollah Habib²

\begin{abstract}
Background: Subclinical hypothyroidism is defined as elevated TSH levels while T4 or FT4 levels are normal. Elevated TSH levels are linked with obesity in adults. In a recent meta-analysis in Iran, 6.1\% of children below 18 had obesity. Due to the low number of studies on the subject in children we, designed the study to assess the relation between BMI Z-score and TSH levels in children and adolescence.

Method: This cross-sectional study was performed in a pediatric endocrinology clinic in Shiraz. Children aged between 2 to 18 years that came to the clinic for routine growth assessment follow up from January till April 2018 were considered. 850 children including 365 boys and 485 girls were included.

Results: Prevalence of subclinical hypothyroidism is increased in higher BMl groups. 9.9, 13.8, 17.2 and 20.5\% of underweight, healthy weight, overweight and obese had subclinical hypothyroidism respectively. Obese and overweight participants had higher odds of subclinical hypothyroidism than those who were not (OR:1.649, $P=$ 0.010, C195\% 1.126-2.413). On the other hand, Subclinical hypothyroid participants had higher odds of overweight or obesity than those who were euthyroid (OR:1.650, $\mathrm{P}=0.010, \mathrm{Cl}$ (95\% 1.128-2.413). When TSH is set as a dependent value, TSH level is increased $(\beta=0.126, r=0.125, P=0.001)$ with an increase in BMI Z-score. When BMl Z-score is set as a dependent value, BMI Z-score is increased $(\beta=0.113, r=0.243, P=0.001)$ with an increase in TSH level.

Conclusion: BMI Z-score and elevated TSH levels are positively correlated however studies should be performed on establishing the causality.
\end{abstract}

Keywords: BMI, BMI Z-score, Children, Thyroid, Hypothyroidism, Iran

\section{Introduction}

Subclinical hypothyroidism is defined as elevated TSH levels while T4 or FT4 levels are normal [1]. It is a common disorder with a prevalence of 1 to $10 \%$ in Adult Community, $[2,3]$ while in the pediatrics population subclinical hypothyroidism is slightly lower than $2 \%[2$, 4]. In adults, subclinical hypothyroidism is linked with abnormal lipid profiles, early signs of impaired cognitive

\footnotetext{
* Correspondence: habib1343@yahoo.com

${ }^{2}$ Department of Endocrinology, School of Medicine, Kazerun Branch, Islamic Azad University., First Floor, Zafar Building, Zand St, PO Box: 71384-37984, Shiraz, Iran

Full list of author information is available at the end of the article
}

function and increased risk of progression into overt hypothyroidism [2, 3, 5-8]. Elevated TSH levels are linked with obesity [9], and they are found to be reversible after weight loss, whether being attained through bariatric surgery or diet [10-15]. These changes are also found to be a consequence of obesity not the cause of it $[12,13,16]$. Similar mechanisms have been hypothesized to explain this elevated TSH levels in the obese population, including an adaptation to increased resting energy expenditure $[10,16]$, increased production of leptinmediated Pro TRH [17-19], increased number of T3

(c) The Author(s). 2020 Open Access This article is licensed under a Creative Commons Attribution 4.0 International License, which permits use, sharing, adaptation, distribution and reproduction in any medium or format, as long as you give appropriate credit to the original author(s) and the source, provide a link to the Creative Commons licence, and indicate if changes were made. The images or other third party material in this article are included in the article's Creative Commons licence, unless indicated otherwise in a credit line to the material. If material is not included in the article's Creative Commons licence and your intended use is not permitted by statutory regulation or exceeds the permitted use, you will need to obtain permission directly from the copyright holder. To view a copy of this licence, visit http://creativecommons.org/licenses/by/4.0/ The Creative Commons Public Domain Dedication waiver (http://creativecommons.org/publicdomain/zero/1.0/) applies to the data made available in this article, unless otherwise stated in a credit line to the data. 
receptors in the hypothalamus [20] and variations in peripheral deiodinase activity $[19,20]$.

Meanwhile, obesity is currently the most common metabolic disorder in many countries [21-23]. The World Health Organization (WHO) categorizes childhood obesity as one of the most serious global health challenges of the twenty-first century affecting many low and middleincome countries [24]. Studies have also shown that it is very likely that childhood obesity persists into adulthood [25]. In a recent meta-analysis in Iran, $6.1 \%$ of children below 18 had obesity. The study also showed a descending trend of obesity prevalence in Iran [26]. Due to the low number of studies correlating TSH and BMI in children we hypothesized that this relation also exists in patients under the age of 18 and obese children have a higher chance of subclinical hypothyroidism. As a result, we designed the study to assess the correlation between BMI Zscore and TSH levels in children and adolescence.

\section{Method}

This is a cross-sectional study performed on data from children with an age of 2 to 18 years that came to a pediatric endocrinology growth assessment clinic for routine growth follow up from January till April 2018 located in the city of Shiraz. The clinic is open to patients 6 days a week with morning and evening shifts. After consent from parents, children were checked for serum thyroid profile levels simultaneously in a non-fast state between $8 \mathrm{AM}$ and $6 \mathrm{PM}$ in a single laboratory. Inclusion criteria for this study were: 1 - an age of 2-18 years; 2 presence of normal free T4 $(0.8-1.8 \mathrm{ng} / \mathrm{dL}) ; 3$ - TSH between 0.3 and $<10 \mathrm{mIU} / \mathrm{L}$. Exclusion criteria were 1Those children who were on levothyroxine therapy at the time of assessment; 2- Ongoing use of medications that may interfere with thyroid function test as antithyroid medications, corticosteroids, oral contraceptives, thiazides.

850 children including 365 (42.9\%) boys and 485 (57.1\%) girls had full inclusion criteria and were selected for the study. Children's weight were measured lightly dressed and without shoes using Seca scale with a precision of $0.1 \mathrm{~kg}$ while Height was measured to the nearest $0.1 \mathrm{~cm}$ using a stadiometer. UptoDate calculators (based on CDC growth charts) were used for measurement of BMI, SDS BMI, BMI percentile. BMI Z-score was calculated by the LMS (lambda, mu, sigma) method based on the reference of BMI distribution of CDC growth charts.

\section{BMI-SDS $=((B M I / m) L-1) / L S$}

The study group was separated into 2-9 year old and 10-18 year old age groups representing before and after start of puberty. Subjects below 5th percentile $(<-1.65$ BMI Z-score) were categorized as underweight, between 5 th and 85 th percentile $(-1.65-+1.04$ BMI Z-score $)$ as healthy weight, between 85th and 95th $(+1.04-+1.65$ BMI Z-score) as overweight and above 95th percentile $(>+1.65$ BMI Z-score) as obese.

Serum TSH was measured using Cobas e411 Analyzer (Mannheim, Germany) with electrochemiluminescence immunoassay (ECLIA) method. Assay performance was controlled using Elecsys PreciControl Universal. Auto Analyser was calibrated using Elecsys TSH CalSet. Interassay coefficients of variation (CVs) for TSH are $1.56 \%$ for $1.37 \mathrm{mIU} / \mathrm{L}$ and $0.08 \%$ for $8.62 \mathrm{mIU} / \mathrm{L}$, respectively. The study was approved by the Islamic Azad University, Kazerun Branch institutional review committee. (reference 1398.125).

TSH levels equal or above 5 were considered abnormal. All participants with high TSH levels were considered for a second remeasurement. For these participants, second TSH levels were considered for the study.

Participants with TSH levels equal or above $5 \mathrm{IU} / \mathrm{m}$ and lower than $10 \mathrm{IU} / \mathrm{ml}$ with normal free T4 levels were categorized as subclinical hypothyroid children based on the 2014 European Thyroid Association guideline on management of subclinical hypothyroidism in children [27]. TSH levels above $10 \mathrm{IU} / \mathrm{ml}$ are considered overt hypothyroidism and as a result were not included in this study.

\section{Statistical analysis}

Comparisons were performed by using ANOVA for continuous variables in Tables 1 and 2 and the Student t-test for Table 3. The relation between BMI Z-score and TSH level was evaluated using multiple variable linear regression adjusted for age and gender. For categorical variables in $\mathrm{Ta}$ bles 4 and 5, comparisons were performed by using chi squared test. Odds ratios for subclinical hypothyroidism in overweight and obese subjects and likewise, overweight and obesity in subclinical hypothyroid subjects was calculated using logistic regression, adjusted for age and gender. A value of $p<0.05$ was considered statistically significant in all comparisons with a confidence interval of $95 \%$. All statistical analysis was performed by using SPSS software version 25.0 (SPSS, Chicago, IL, USA).

\section{Results}

Table 1 shows anthropometric and laboratory values of subjects in different BMI and thyroid categories. Subjects had a statistical difference in their age and gender. Therefore, these parameters had to be adjusted when calculating the correlation between TSH and BMI Zscore. Median and interquartile range (IQR) of time of day at which the subjects had their blood samples taken was 13:00 (IQR: 9: 40-16:25) for euthyroid subjects and 11:25 (IQR: 8: 35-15:12) for subclinical hypothyroid subjects. No significant difference could be found between the two based on Mann-Whitney $\mathrm{U}$ test $(p=0.070)$. 
Table 1 Anthropometric and laboratory values of the study subjects

\begin{tabular}{|c|c|c|c|c|c|c|c|c|}
\hline \multicolumn{6}{|c|}{ Based on BMI category } & \multicolumn{3}{|c|}{ Based on thyroid status } \\
\hline & $\begin{array}{l}\text { Underweight } \\
\text { (141) }\end{array}$ & $\begin{array}{l}\text { Healthy weight } \\
(369)\end{array}$ & $\begin{array}{l}\text { Overweight } \\
(116)\end{array}$ & Obese (224) & $P$ & $\begin{array}{l}\text { Euthyroid } \\
(719)\end{array}$ & $\begin{array}{l}\text { Subclinical Hypothyroid } \\
(131)\end{array}$ & $P$ \\
\hline Age & $8.80 \pm 3.48$ & $9.57 \pm 3.56$ & $11.03 \pm 3.30$ & $10.38 \pm 2.94$ & $\begin{array}{l}< \\
0.001^{*}\end{array}$ & $9.84 \pm 3.45$ & $9.98 \pm 3.26$ & 0.663 \\
\hline Height & $123.78 \pm 19.03$ & $131.08 \pm 20.63$ & $142.44 \pm 16.40$ & $\begin{array}{l}142.72 \pm \\
15.01\end{array}$ & $\begin{array}{l}< \\
0.001 *\end{array}$ & $133.95 \pm 20.10$ & $137.43 \pm 17.52$ & 0.064 \\
\hline Weight & $20.97 \pm 7.67$ & $30.54 \pm 13.00$ & $46.54 \pm 15.83$ & $57.72 \pm 19.90$ & $\begin{array}{l}< \\
0.001^{*}\end{array}$ & $37.72 \pm 20.25$ & $41.49 \pm 19.31$ & $0.049^{*}$ \\
\hline Male (\%) & $56.0 \%$ & $36.0 \%$ & $36.2 \%$ & $49.6 \%$ & $\begin{array}{l}< \\
0.001^{*}\end{array}$ & $42.6 \%$ & $45.0 \%$ & 0.598 \\
\hline BMI & $13.23 \pm 1.07$ & $16.84 \pm 2.47$ & $22.12 \pm 2.91$ & $27.49 \pm 5.21$ & $\begin{array}{l}< \\
0.001^{*}\end{array}$ & $19.57 \pm 6.22$ & $20.88 \pm 6.01$ & $0.026^{*}$ \\
\hline $\begin{array}{l}\text { BMI Z- } \\
\text { score }\end{array}$ & $-2.86 \pm 1.13$ & $-0.25 \pm 0.78$ & $1.36 \pm 0.18$ & $2.18 \pm 0.39$ & $\begin{array}{l}< \\
0.001 *\end{array}$ & $0.10 \pm 1.8334$ & $0.60 \pm 1.81$ & $0.005^{*}$ \\
\hline TSH & $2.89 \pm 1.64$ & $3.05 \pm 1.85$ & $3.22 \pm 1.77$ & $3.53 \pm 2.13$ & $0.005^{*}$ & $2.54 \pm 1.14$ & $6.65 \pm 1.41$ & $\begin{array}{l}< \\
0.001^{*}\end{array}$ \\
\hline FT4 & $\begin{array}{l}1.41 \pm \\
0.24\end{array}$ & $\begin{array}{l}1.43 \pm \\
0.25\end{array}$ & $\begin{array}{l}1.39 \pm \\
0.27\end{array}$ & $\begin{array}{l}1.39 \pm \\
0.26\end{array}$ & 0.221 & $\begin{array}{l}1.41 \pm \\
0.25\end{array}$ & $\begin{array}{l}1.43 \pm \\
0.27\end{array}$ & 0.247 \\
\hline
\end{tabular}

Abbreviations: BMI, body mass index; TSH, thyroid stimulating hormone; FT4, free T4

Table 2 demonstrates mean thyroid parameters in the study subjects based on their respective BMI group. A statistically significant increase in mean TSH levels in higher BMI groups is demonstrated. It's important to note that when comparing mean TSH levels in the age and gender subgroups, the difference is statistically significant in the overall male group, overall 2-9 year old age group and the male 2-9 year old age group.

Table 3 shows mean BMI parameters in euthyroid and subclinical hypothyroid children. A statistically significant difference is found in mean BMI and BMI Z-score when comparing euthyroid and subclinical hypothyroid

Table 2 Mean thyroid stimulating hormone and free T4 levels based on subject BMI group

\begin{tabular}{|c|c|c|c|c|c|c|c|}
\hline & & & Underweight & Healthy weight & Overweight & Obese & $P$ \\
\hline \multirow[t]{6}{*}{ All ages } & All (850) & TSH & $2.89 \pm 1.64$ & $3.05 \pm 1.85$ & $3.22 \pm 1.77$ & $3.53 \pm 2.13$ & $0.005^{*}$ \\
\hline & & $\mathrm{FT4}$ & $\begin{array}{l}1.41 \pm \\
0.24\end{array}$ & $\begin{array}{l}1.43 \pm \\
0.25\end{array}$ & $\begin{array}{l}1.39 \pm \\
0.27\end{array}$ & $\begin{array}{l}1.39 \pm \\
0.26\end{array}$ & 0.221 \\
\hline & Male (365) & TSH & $\begin{array}{l}2.78 \pm \\
1.55\end{array}$ & $\begin{array}{l}3.16 \pm \\
1.77\end{array}$ & $\begin{array}{l}3.145 \pm \\
1.69\end{array}$ & $3.75 \pm 1.94$ & $0.002^{*}$ \\
\hline & & $\mathrm{FT} 4$ & $1.41 \pm 0.23$ & $1.41 \pm 0.24$ & $1.30 \pm 0.26$ & $1.42 \pm 0.23$ & $0.040^{*}$ \\
\hline & Female (485) & TSH & $3.02 \pm 1.75$ & $3.00 \pm 1.90$ & $3.27 \pm 1.83$ & $3.31 \pm 2.28$ & 0.457 \\
\hline & & $\mathrm{FT} 4$ & $1.40 \pm 0.25$ & $1.44 \pm 0.26$ & $1.44 \pm 0.26$ & $1.36 \pm 0.28$ & $0.045^{*}$ \\
\hline \multirow[t]{6}{*}{ 2-9year olds } & All (429) & TSH & $2.79 \pm 1.58$ & $\begin{array}{l}2.98 \pm \\
1.62\end{array}$ & $\begin{array}{l}3.24 \pm \\
1.83\end{array}$ & $\begin{array}{l}3.64 \pm \\
2.18\end{array}$ & $0.005^{*}$ \\
\hline & & $\mathrm{FT4}$ & $1.44 \pm 0.25$ & $1.45 \pm 0.24$ & $1.44 \pm 0.25$ & $1.40 \pm 0.27$ & 0.450 \\
\hline & Male (155) & TSH & $2.71 \pm 1.66$ & $3.34 \pm 1.84$ & $2.23 \pm 1.37$ & $4.05 \pm 1.82$ & $0.003^{*}$ \\
\hline & & $\mathrm{FT} 4$ & $1.45 \pm 0.24$ & $1.47 \pm 0.21$ & $1.44 \pm 0.19$ & $1.43 \pm 0.23$ & 0.872 \\
\hline & Female (274) & TSH & $2.88 \pm 1.50$ & $2.81 \pm 1.48$ & $3.43 \pm 1.86$ & $3.37 \pm 2.36$ & 0.084 \\
\hline & & $\mathrm{FT} 4$ & $1.42 \pm 0.25$ & $1.44 \pm 0.25$ & $1.44 \pm 0.26$ & $1.38 \pm 0.29$ & 0.504 \\
\hline \multirow[t]{6}{*}{ 10-18 year olds } & All (421) & TSH & $3.03 \pm 1.72$ & $3.15 \pm 2.10$ & $3.21 \pm 1.74$ & $3.44 \pm 2.09$ & 0.521 \\
\hline & & $\mathrm{FT4}$ & $1.36 \pm 0.23$ & $1.41 \pm 0.27$ & $1.36 \pm 0.27$ & $1.38 \pm 0.25$ & 0.463 \\
\hline & Male (210) & $\mathrm{TSH}$ & $2.88 \pm 1.41$ & $2.99 \pm 1.70$ & $3.33 \pm 1.70$ & $3.58 \pm 2.00$ & 0.138 \\
\hline & & $\mathrm{FT4}$ & $1.36 \pm 0.21$ & $1.36 \pm 0.26$ & $1.27 \pm 0.26$ & $1.41 \pm 0.23$ & 0.057 \\
\hline & Female (211) & TSH & $3.24 \pm 2.11$ & $3.26 \pm 2.34$ & $3.09 \pm 1.80$ & $3.24 \pm 2.20$ & 0.984 \\
\hline & & $\mathrm{FT} 4$ & $1.36 \pm 0.25$ & $1.44 \pm 0.27$ & $1.44 \pm 0.26$ & $1.34 \pm 0.27$ & 0.087 \\
\hline
\end{tabular}


Table 3 Mean body mass index (BMI) and BMI Z-score based on subject thyroid status

\begin{tabular}{|c|c|c|c|c|c|}
\hline & & & Euthyroid & Subclinical Hypothyroid & $P$ \\
\hline \multirow[t]{6}{*}{ All ages } & All (850) & BMI & $19.57 \pm 6.22$ & $20.88 \pm 6.01$ & $0.026^{*}$ \\
\hline & & BMI Z-score & $0.10 \pm 1.8334$ & $0.60 \pm 1.81$ & $0.005^{*}$ \\
\hline & Male (365) & BMI & $19.73 \pm 6.57$ & $21.57 \pm 6.73$ & 0.051 \\
\hline & & BMI Z-score & $-0.05 \pm 2.04$ & $0.51 \pm 2.12$ & 0.054 \\
\hline & Female (485) & BMI & $19.44 \pm 5.94$ & $20.31 \pm 5.34$ & 0.247 \\
\hline & & BMI Z-score & $0.22 \pm 1.66$ & $0.67 \pm 1.52$ & $0.032^{*}$ \\
\hline \multirow[t]{6}{*}{ 2-9 year olds } & All (429) & BMI & $17.30 \pm 4.60$ & $19.57 \pm 5.71$ & $0.003^{*}$ \\
\hline & & BMI Z-score & $-0.15 \pm 1.88$ & $0.59 \pm 1.99$ & $0.004^{*}$ \\
\hline & Male (155) & BMI & $16.61 \pm 4.50$ & $18.51 \pm 5.84$ & 0.120 \\
\hline & & BMI Z-score & $-0.59 \pm 2.15$ & $-0.05 \pm 2.55$ & 0.248 \\
\hline & Female (274) & BMI & $17.68 \pm 4.62$ & $20.27 \pm 5.58$ & $0.001^{*}$ \\
\hline & & BMI Z-score & $0.10 \pm 1.67$ & $1.00 \pm 1.39$ & $0.000^{*}$ \\
\hline \multirow[t]{6}{*}{ 10-18year olds } & All (421) & BMI & $21.85 \pm 6.78$ & $22.29 \pm 6.06$ & 0.635 \\
\hline & & BMI Z-score & $0.36 \pm 1.75$ & $0.61 \pm 1.61$ & 0.288 \\
\hline & Male (210) & BMI & $21.98 \pm 6.91$ & $24.16 \pm 6.40$ & 0.099 \\
\hline & & BMI Z-score & $0.34 \pm 1.88$ & $0.98 \pm 1.55$ & 0.067 \\
\hline & Female (211) & BMI & $21.73 \pm 6.65$ & $20.36 \pm 5.08$ & 0.277 \\
\hline & & BMI Z-score & $0.38 \pm 1.62$ & $0.22 \pm 1.59$ & 0.621 \\
\hline
\end{tabular}

\section{Abbreviations: BMI, body mass index;}

children. The table also illustrates that when comparing mean BMI Z-score in the age and gender subgroups, the difference between thyroid groups is statistically significant in the overall female group, overall 2-9 year old age group and the female 2-9 year old age group.

When TSH is set as a dependent value (effect of BMI Z-score on TSH levels) for correlation of TSH levels and BMI Z-score based on linear regression, TSH level is increased approximately $0.126 \mathrm{mIU} / \mathrm{L}$ with every 1 score increase in BMI Z-score with a correlation coefficient of 0.125 adjusted for age and gender $(p=0.001)$. However, When BMI Z-score is set as a dependent value (effect of TSH level on BMI Z-score), BMI Z-score is increased approximately 0.113 with every $1 \mathrm{mIU} / \mathrm{L}$ increase in TSH levels with a correlation coefficient of $0.243(\mathrm{p}=$ 0.001). Adjusted linear correlation of TSH and BMI Zscore was also statistically significant in the 2-9 year old age group (TSH dependent value, $r=0.185, \beta=0.164$, $p=0.000$ ) and the male group (TSH dependent value, $\mathrm{r}=0.176, \beta=0.157, \mathrm{p}=0.001$ ) while this was not true in the 10-18 year old age group $(p=0.132)$ and the female group $(p=0.078)$.

Based on Table 4, the prevalence of subclinical hypothyroidism is increased in higher BMI groups. 9.9, 13.8, 17.2 and $20.5 \%$ of underweight, healthy weight, overweight and obese had subclinical hypothyroidism.

Table 4 Prevalence of Subclinical hypothyroidism in each BMI category

\begin{tabular}{|c|c|c|c|c|c|c|}
\hline & & Underweight & Healthy weight & Overweight & Obese & $P$ \\
\hline \multirow[t]{3}{*}{ All ages } & All subjects & $9.9 \%$ & $13.8 \%$ & $17.2 \%$ & $20.5 \%$ & $0.032^{*}$ \\
\hline & Male subjects & $10.1 \%$ & $14.3 \%$ & $11.9 \%$ & $24.3 \%$ & $0.037^{*}$ \\
\hline & Female subjects & $9.7 \%$ & $13.6 \%$ & $20.3 \%$ & $16.8 \%$ & 0.297 \\
\hline \multirow[t]{3}{*}{ 2-9 year olds } & All subjects & $9.6 \%$ & $12.1 \%$ & $23.9 \%$ & $24.8 \%$ & $0.005^{*}$ \\
\hline & Male subjects & $11.1 \%$ & $15.9 \%$ & $0.0 \%$ & $30.0 \%$ & 0.065 \\
\hline & Female subjects & $7.9 \%$ & $10.3 \%$ & $28.2 \%$ & $21.3 \%$ & $0.011^{*}$ \\
\hline \multirow[t]{3}{*}{ 10-18 year olds } & All subjects & $10.3 \%$ & $15.9 \%$ & $12.9 \%$ & $17.1 \%$ & 0.624 \\
\hline & Male subjects & $8.8 \%$ & $12.9 \%$ & $14.3 \%$ & $21.1 \%$ & 0.345 \\
\hline & Female subjects & $12.5 \%$ & $18.0 \%$ & $11.4 \%$ & $11.5 \%$ & 0.642 \\
\hline
\end{tabular}


Table 5 Distribution of euthyroid and subclinical hypothyroid children based on their BMI category

\begin{tabular}{|c|c|c|c|c|c|c|c|c|c|c|}
\hline & & \multicolumn{3}{|l|}{ All ages } & \multicolumn{3}{|c|}{ 2-9year olds } & \multicolumn{3}{|c|}{ 10-18 year olds } \\
\hline & & Euthyroid & $\begin{array}{l}\text { Subclinical } \\
\text { Hypothyroid }\end{array}$ & $P$ & Euthyroid & $\begin{array}{l}\text { Subclinical } \\
\text { Hypothyroid }\end{array}$ & $P$ & Euthyroid & $\begin{array}{l}\text { Subclinical } \\
\text { Hypothyroid }\end{array}$ & $P$ \\
\hline \multirow[t]{4}{*}{ All subjects } & Underweight & $17.7 \%$ & $10.7 \%$ & $0.032^{*}$ & $20.8 \%$ & $11.8 \%$ & 0.005 & $14.5 \%$ & $9.5 \%$ & 0.624 \\
\hline & $\begin{array}{l}\text { Healthy } \\
\text { weight }\end{array}$ & $44.2 \%$ & $38.9 \%$ & & $48.5 \%$ & $35.3 \%$ & & $39.9 \%$ & $42.9 \%$ & \\
\hline & Overweight & $13.4 \%$ & $15.3 \%$ & & $9.7 \%$ & $16.2 \%$ & & $17.0 \%$ & $14.3 \%$ & \\
\hline & Obese & $24.8 \%$ & $35.1 \%$ & & $21.1 \%$ & $36.8 \%$ & & $28.5 \%$ & $33.3 \%$ & \\
\hline \multirow{4}{*}{$\begin{array}{l}\text { Male } \\
\text { subjects }\end{array}$} & Underweight & $23.2 \%$ & $13.6 \%$ & $0.037^{*}$ & $31.3 \%$ & $18.5 \%$ & 0.065 & $17.4 \%$ & $9.4 \%$ & 0.345 \\
\hline & $\begin{array}{l}\text { Healthy } \\
\text { weight }\end{array}$ & $37.3 \%$ & $32.2 \%$ & & $41.4 \%$ & $37.0 \%$ & & $34.3 \%$ & $28.1 \%$ & \\
\hline & Overweight & $12.1 \%$ & $8.5 \%$ & & $5.5 \%$ & $0.0 \%$ & & $16.9 \%$ & $15.6 \%$ & \\
\hline & Obese & $27.5 \%$ & $45.8 \%$ & & $21.9 \%$ & $44.4 \%$ & & $31.5 \%$ & $46.9 \%$ & \\
\hline \multirow{4}{*}{$\begin{array}{l}\text { Female } \\
\text { subjects }\end{array}$} & Underweight & $13.6 \%$ & $8.3 \%$ & 0.297 & $15.0 \%$ & $7.3 \%$ & $0.011^{*}$ & $11.7 \%$ & $9.7 \%$ & 0.642 \\
\hline & $\begin{array}{l}\text { Healthy } \\
\text { weight }\end{array}$ & $49.4 \%$ & $44.4 \%$ & & $52.4 \%$ & $34.1 \%$ & & $45.6 \%$ & $58.1 \%$ & \\
\hline & Overweight & $14.3 \%$ & $20.8 \%$ & & $12.0 \%$ & $26.8 \%$ & & $17.2 \%$ & $12.9 \%$ & \\
\hline & Obese & $22.8 \%$ & $26.4 \%$ & & $20.6 \%$ & $31.7 \%$ & & $25.6 \%$ & $19.4 \%$ & \\
\hline
\end{tabular}

Abbreviations: BMI, body mass index

On the other hand, based on Table 5, subclinical hypothyroid subjects have a higher prevalence of overweight or obesity than euthyroid subjects. (Table 4 and Table 5).

Based on logistic regression adjusted for age and gender, obese and overweight participants had 1.649 (CI95\%: 1.126-2.413, $p=0.010$ ) times higher odds of subclinical hypothyroidism than those who were not obese or overweight. On the other hand, Subclinical hypothyroid participants had 1.650 (CI95\%: 1.128-2.413, $\mathrm{p}=0.010$ ) times higher odds of overweight or obesity than those who were euthyroid.

Figure 1 shows the scatter plot of subjects in this study based on their BMI Z-score, TSH and free T4 levels. (Fig. 1) A significant linear correlation between seum TSH levels and BMI Z-score is demonstrated.

\section{Discussion}

This study reveals that a linear correlation exists between serum TSH levels and BMI Z-score in children without overt hypothyroidism especially in those under the age of 10. The study also reveals the prevalence of subclinical hypothyroidism in southern Iranian children based on their BMI status.

Prevalence of subclinical hypothyroidism in adults is reported to be in a range of 1 to $12.5 \%[3,28]$. In children, little information is available on the prevalence of $\mathrm{SH}$. In various studies, the prevalence rate ranged between 1.7 to $9.5 \%$ [28]. In the study by Jin HY, the prevalence rate was $12.8 \%$ in healthy children and $24.3 \%$ in obese children [29] and in our study, it was $13.8 \%$ in healthy children and $20.5 \%$ in obese children. The reason for this amount of variation in prevalence rate is probably due to either different selection of cut-offs for a normal or abnormal range of serum TSH levels or once vs more than once measurements of serum TSH levels in the study participants.

In most studies, $\mathrm{SH}$ has a higher prevalence in overweight and obese children [9, 11, 29-34].

According to Marras V et al., of the 468 obese participants, 109 had abnormal thyroid hormone concentrations. After 6 months of lifestyle intervention in 43 participants, thyroid hormones normalized in 27 of the patients with decreased BMI Z-score [9]. Reinehr T et al. found that although obesity and higher TSH levels are correlated, lipid serum components had no effect on serum TSH levels. Weight loss in 49 of the 246 obese participants led to a significant reduction of TSH [11].

Jin HY, however, found that besides TSH levels being positively correlated with BMI Z-score, the concentrations of total cholesterol and triglyceride were also positively correlated with the TSH concentrations following adjustment for age and BMI Z-score [29].

In the study by Stitche H, TSH and T3 levels are significantly increased in obese children. Obesity had no effect on serum T4, urinary iodine excretion, and AntiTPO Ab, however [30].

In a study by Ghergherehchi $\mathrm{R}$ et al. on 323 children in Iran, $14.7 \%$ of obese participants had subclinical hypothyroidism, which is lower than our results, while $6.8 \%$ of normal subjects had SH. BMI Z-score was positively correlated with TSH levels [31].

According to a study by Bhowmick SK et al., $11.7 \%$ of obese participants had $\mathrm{SH}$ compared to $0.7 \%$ of healthy 

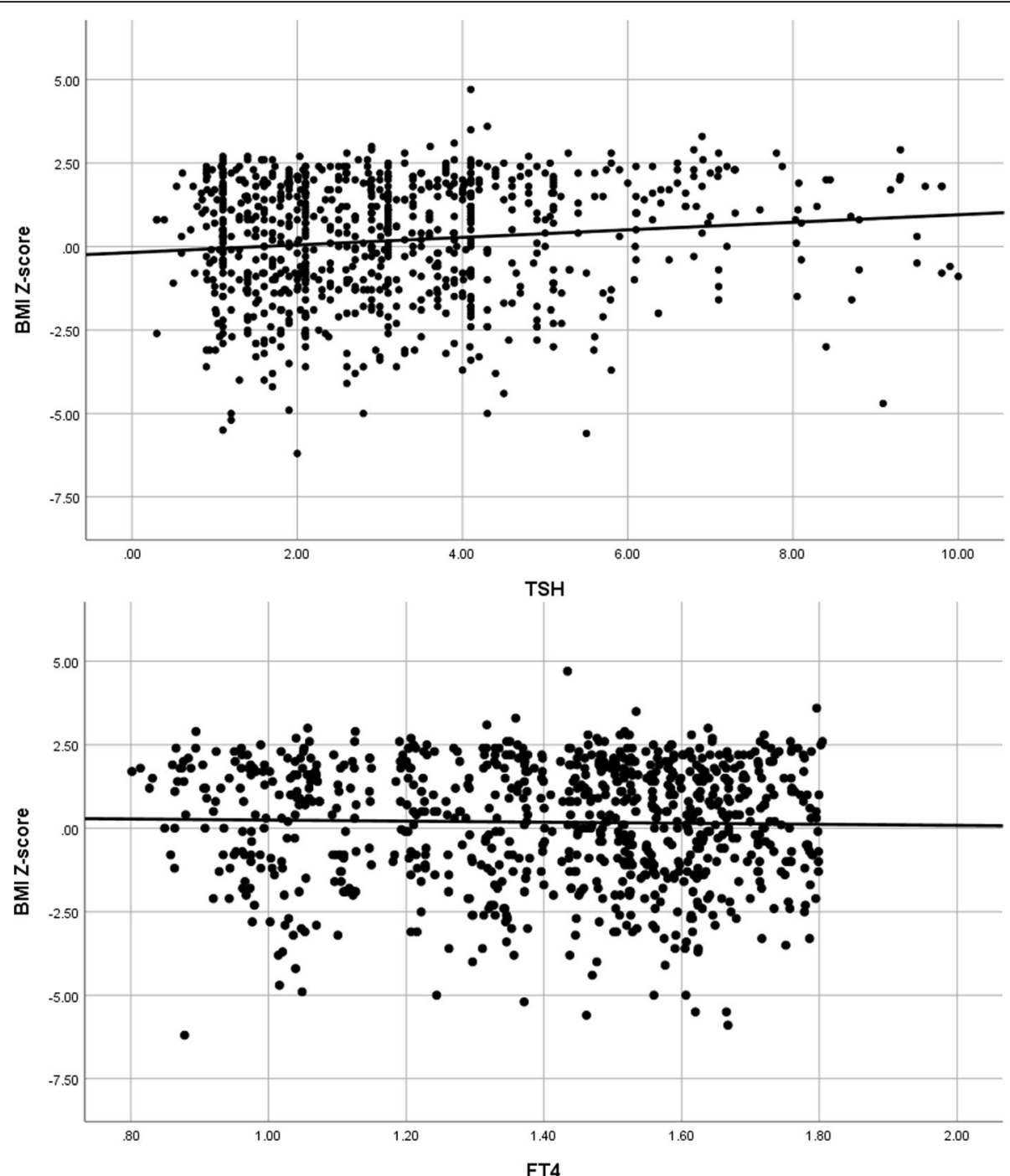

Fig. 1 Linear correlation of BMI Z-score with TSH and FT4 levels in all 850 participants of this study

weight children. Mean TSH levels in non-positive Anti TPO Ab obese participants was $5.33 \mathrm{mIU} / \mathrm{L}$. [33].

In another study by Dekelbab BH, 10.8\% of 185 obese participants with negative Anti TPO Ab had TSH levels higher than $4 \mathrm{mIU} / \mathrm{L}$. Mean TSH in the subjects was $7.51 \mathrm{mUI} / \mathrm{L}$. [34].

According to our findings, there is a significant statistical difference between BMI Z-score in euthyroid vs subclinical hypothyroid children. The average BMI Zscore for euthyroid children is $0.102 \pm 1.8334$ and for subclinical hypothyroid children is $0.595 \pm 1.8076(P=$ 0.005).

In other words, with an increase in BMI Z-score, TSH level is increased, and on the other hand, as the TSH levels increase, the prevalence of higher BMI Z score also increases. Which one is the cause and which is the causality? The correct answer to this question cannot be given. However, while in our study the correlation coefficient is stronger when TSH is set as an independent value and BMI Z-score as a dependent, in many studies weight loss leads to a lower TSH level [10-15] and in a study by Knudsen $\mathrm{N}$ et al., a positive correlation between weight gain over 5 years and a progressive increase in TSH was noted [35]. Based on this fact, Peeters RP believes that subclinical hypothyroidism is an unlikely cause of obesity [36]. Another hypothesis based on this assumption is that because elevated serum TSH levels are reversible after weight loss, this may not be 'true' subclinical hypothyroidism and may possibly be a result of adaptive responses to thyrotropic feedback control i.e. obesity leading to increase in serum leptin-mediated Pro TRH [17-19] and increase in resting energy expenditure $[10,16]$ which in turn, leads to a higher serum TSH level. However, what we don't know at the time of this 
study is that do any of these 'reversible' subclinical hypothyroid patients eventually lead to overt hypothyroidism in the long term? To answer this question, a long term prospective study is needed on subjects demonstrating decrease in TSH levels after weight loss.

Meanwhile, Manji $\mathrm{N}$ et al. found no correlation between TSH levels and BMI Z-score in euthyroid participants [37].

\section{Study limitations}

The most important limitation of this study is that while it illustrates a positive link between serum TSH levels and BMI Z-score, it does not reveal the causality of this link. Is obesity causing higher levels of serum TSH, or is progression of subclinical hypothyroidism causing weight gain? Based on our study, the correlation coefficient is higher when BMI Z-score is set as the dependent value. This may mean that it is subclinical hypothyroidism that is causing obesity, not the other way around. However, this is not definite and decrease in serum TSH levels during weight loss as seen in other studies may counter that hypothesis. More research on the cause and causality of obesity and subclinical hypothyroidism should be performed. Another limitation is that while Anti-TPO Ab levels are not required for a subclinical hypothyroidism diagnosis, they are recommended for considering therapeutic treatment of the disease and they would have certainly helped in a better analysis of the subjects in this study. This study also did not record subject puberty status, which may affect serum TSH levels. Regarding the time span at which the blood specimen were collected, it should be noted that despite the diurnal variation in TSH levels, this variation will not influence the diagnostic interpretation of results since reference intervals for TSH are established with the variation between $8 \mathrm{AM}$ and $6 \mathrm{PM}$ in mind [38]. We found no significant difference in proportion of subclinical hypothyroid patients in morning $(18.3 \%$ of $n=229)$ vs evening (11.3\% of $n=124)$ shifts $(p=0.083)$ and the time of day sampling between euthyroid and subclinical hypothyroid subjects (change of shift at 2:30 PM).

\section{Conclusion}

Prevalence of subclinical hypothyroidism is higher in overweight and obese children and increase in BMI Zscore and serum TSH levels are closely linked. However, because weight loss results in normalization of serum TSH levels, it can be assumed that elevated TSH levels in these subjects are due to adaptive responses of thyrotropic feedback control to obesity rather than "true" hypothyroidism. Furthermore, is the treatment of subclinical hypothyroidism in children also effective for weight loss? That is unclear and more extensive studies are needed to evaluate the eventual outcome of $\mathrm{SH}$ in children. Finally, based on results of this study, a thyroid profile test should be considered in approach to obesity in children. If subclinical hypothyroidism is found in obese children, a weight loss plan may lead to a decrease in serum TSH levels and a drug therapy may not be needed.

\section{Abbreviations \\ BMI: body mass index; TSH: thyroid stimulating hormone; FT4: free T4; $\mathrm{Cl}$ : confidence interval; $\mathrm{CDC}$ : center for disease control and prevention; SH: subclinical hypothyroidism; IQR: interquartile range}

\section{Acknowledgments}

The authors are grateful to individuals who participated in this survey and to Boghrat Laboratory for assisting in biochemical tests. Special thanks to our dear colleagues Dr. Zinatosadat Hejrati and Dr. Zahra Kheirandish for making this study possible.

\section{Authors' Contributions}

AshH, MM: Collected the data, performed data analysis, interpreted the data and wrote the manuscript. AsaH: Designed the study, Involved in critical revision of the manuscript. All authors read and approved the final version of the manuscript. Corresponding author: Correspondence to Asadollah Habib.

\section{Funding}

No external funding was provided. The work was conducted by authors as part of their regular duties or on a volunteer basis.

\section{Availability of data and materials}

The datasets used during the current study are not available due to confidentiality policy set by the clinic.

\section{Ethics approval and consent to participate}

The study was approved by the Islamic Azad University, Kazerun Branch intuitional review committee (reference 1398.125) based on the Declaration of Helsinki.

\section{Consent for publication}

Not applicable.

\section{Competing interests}

The authors declare that they have no competing interests.

\section{Author details}

${ }^{1}$ School of Medicine, Shiraz University of Medical Sciences, Shiraz, Iran. ${ }^{2}$ Department of Endocrinology, School of Medicine, Kazerun Branch, Islamic Azad University., First Floor, Zafar Building, Zand St, PO Box: 71384-37984, Shiraz, Iran.

Received: 20 March 2020 Accepted: 3 June 2020

Published online: 13 June 2020

References

1. Salerno M, Capalbo D, Cerbone M, De Luca F. Subclinical hypothyroidism in childhood - current knowledge and open issues. Nat Rev Endocrinol. 2016;12:734-46.

2. Canaris GJ, Manowitz NR, Mayor G, Ridgway EC. The Colorado thyroid disease prevalence study. Arch Intern Med. 2000;160(4):526-34.

3. Biondi B, Cooper DS. The clinical significance of subclinical thyroid dysfunction. Endocr Rev. 2008;29(1):76-131.

4. Paoli-valeri M, Mamán-alvarado D, Jiménez-lópez V, Arias-ferreira A, Bianchi G, Arata-bellabarba G. Frequency of subclinical hypothyroidism among healthy children and those with neurological conditions in the state of Mérida, Venezuela. Investig Clin. 2003:44(3):209-18.

5. Danese MD, Ladenson PW, Meinert CL, Powe NR. Clinical review 115: effect of thyroxine therapy on serum lipoproteins in patients with mild thyroid failure: a quantitative review of the literature. J Clin Endocrinol Metab. 2000; 85(9):2993-3001

6. Ochs N, Auer R, Bauer DC, et al. Meta-analysis: subclinical thyroid dysfunction and the risk for coronary heart disease and mortality. Ann Intern Med. 2008;148(11):832-45. 
7. Monzani F. Del guerra P, Caraccio N, et al. subclinical hypothyroidism: neurobehavioral features and beneficial effect of L-thyroxine treatment. Clin Investig. 1993;71(5):367-71.

8. Baldini IM, Vita A, Mauri MC, et al. Psychopathological and cognitive features in subclinical hypothyroidism. Prog Neuro-Psychopharmacol Biol Psychiatry. 1997;21(6):925-35.

9. Marras V, Casini MR, Pilia S, et al. Thyroid function in obese children and adolescents. Horm Res Paediatr. 2010;73:193-7.

10. Reinehr T. Thyroid function in the nutritionally obese child and adolescent. Curr Opin Pediatr. 2011;23(4):415-20.

11. Reinehr T. De Sousa G, Andler W. Hyperthyrotropinemia in obese children is reversible after weight loss and is not related to lipids. J Clin Endocrinol Metab. 2006;91(8):3088-91.

12. Reinehr T, Isa A. De Sousa G, Dieffenbach $R$, Andler W. thyroid hormones and their relation to weight status. Horm Res. 2008:70(1):51-7.

13. Reinehr $T$, Andler W. Thyroid hormones before and after weight loss in obesity. Arch Dis Child. 2002:87(4):320-3.

14. Sari R, Balci MK, Altunbas H, Karayalcin U. The effect of body weight and weight loss on thyroid volume and function in obese women. Clin Endocrinol. 2003;59(2):258-62.

15. Rotondi M, Magri F, Chiovato L. Thyroid and obesity: not a one-way interaction. J Clin Endocrinol Metab. 2011;96(2):344-6.

16. Reinehr T. Obesity and thyroid function. Mol Cell Endocrinol. 2010;316(2): 165-71.

17. Légrádi G, Emerson CH, Ahima RS, Flier JS, Lechan RM. Leptin prevents fasting-induced suppression of prothyrotropin-releasing hormone messenger ribonucleic acid in neurons of the hypothalamic paraventricular nucleus. Endocrinology. 1997;138(6):2569-76.

18. Nillni EA, Vaslet C, Harris M, Hollenberg A, Bjørbak C, Flier JS. Leptin regulates prothyrotropin-releasing hormone biosynthesis. Evidence for direct and indirect pathways. J Biol Chem. 2000;275(46):36124-33.

19. Harris M, Aschkenasi $C$, Elias CF, et al. Transcriptional regulation of the thyrotropin-releasing hormone gene by leptin and melanocortin signaling. J Clin Invest. 2001:107(1):111-20.

20. Burman $K D$, Latham KR, Djuh $Y Y$, et al. Solubilized nuclear thyroid hormone receptors in circulating human mononuclear cells. J Clin Endocrinol Metab. 1980;51(1):106-16.

21. Caterson ID, Gill TP. Obesity: epidemiology and possible prevention. Clin Endocrinol Metab. 2002;16(4):595-610.

22. James WPT. The epidemiology of obesity: the size of the problem. J Intern Med. 2008;263(4):336-52.

23. Tanner RM, Brown TM. Muntner P. Epidemiology of Obesity, the Metabolic Syndrome, and Chronic Kidney Disease Curr Hypertens Rep. 2012;14(2):152-9.

24. Childhood overweight and obesity. World Health Organization. (WHO Media center URL: http://www.who.int/mediacentre/factsheets/fs311/en/ [accessed 2015-12-24]).

25. Simmonds M, Burch J, Llewellyn A, Griffiths C, Yang H, Owen C, et al. The use of measures of obesity in childhood for predicting obesity and the development of obesity-related diseases in adulthood: a systematic review and meta-analysis. Health technology assessment (Winchester, England). 2015;19(43):1-336.

26. Rahmani A, Sayehmiri K, Asadollahi K, Sarokhani D, Islami F, Sarokhani M. Investigation of the prevalence of obesity in Iran: a systematic review and meta-analysis study. Acta Med Iran. 2015;53(10):596-607.

27. Lazarus J, Brown RS, Daumerie C, Hubalewska-dydejczyk A, Negro R, Vaidya B. 2014 European thyroid association guidelines for the management of subclinical hypothyroidism in pregnancy and in children. Eur Thyroid J. 2014;3(2):76-94.

28. Catli G, Abaci A, Buyukgebiz A, Bober E. Subclinical hypothyroidism in childhood and adolescence. J Pediatr Endocrinol Metab. 2014;27:1049-57.

29. Jin HY. Prevalence of subclinical hypothyroidism in obese children or adolescents and association between thyroid hormone and the components of metabolic syndrome. J Paediatr Child Health. 2018;54(9): 975-80.

30. Stichel $H$, l'Allemand D, Gruters A. Thyroid function and obesity in children and adolescents. Horm Res. 2000;54:14-9.

31. Ghergherehchi R, Hazhir N. Thyroid hormonal status among children with obesity. Ther Adv Endocrinol Metab. 2015;6(2):51-5.

32. Radetti $G$, Kleon W, Buzi $F$, et al. Thyroid function and structure are affected in childhood obesity. J Clin Endocrinol Metab. 2008;93(12):4749-54.
33. Bhowmick SK, Dasari G, Levens KL, Rettig KR. The prevalence of elevated serum thyroid-stimulating hormone in childhood/adolescent obesity and of autoimmune thyroid diseases in a subgroup. J Natl Med Assoc. 2007;99(7): $773-6$.

34. Dekelbab BH. Abou ouf HA, Jain I. prevalence of elevated thyroidstimulating hormone levels in obese children and adolescents. Endocr Pract. 2010;16(2):187-90.

35. Knudsen N, Laurberg P, Rasmussen LB, et al. Small differences in thyroid function may be important for body mass index and the occurrence of obesity in the population. J Clin Endocrinol Metab. 2005;90(7):4019-24.

36. Peeters RP. Subclinical hypothyroidism. N Engl J Med. 2017:376(26):2556-65.

37. Manji N, Boelaert K, Sheppard MC, Holder RL, Gough SC, Franklyn JA. Lack of association between serum TSH or free T4 and body mass index in euthyroid subjects. Clin Endocrinol. 2006;64(2):125-8.

38. Deary M, Buckey T, Soldin OP. TSH - Clinical Aspects of its Use in Determining Thyroid Disease in the Elderly. How Does it Impact the Practice of Medicine in Aging?. Adv Pharmacoepidemiol Drug Saf. 2012; 1(119):9369.

\section{Publisher's Note}

Springer Nature remains neutral with regard to jurisdictional claims in published maps and institutional affiliations.
Ready to submit your research? Choose BMC and benefit from:

- fast, convenient online submission

- thorough peer review by experienced researchers in your field

- rapid publication on acceptance

- support for research data, including large and complex data types

- gold Open Access which fosters wider collaboration and increased citations

- maximum visibility for your research: over $100 \mathrm{M}$ website views per year

At BMC, research is always in progress.

Learn more biomedcentral.com/submission 